\title{
ИСПОЛЬЗОВАНИЕ СПЕЛЬТЫ (Triticum spelta L.) В СЕЛЕКЦИИ НА КАЧЕСТВО ЗЕРНА ТРИТИКАЛЕ (Triticosecale Wittmack)
}

\author{
И.П. ДИОРДИЕВАํㅛ, Я.С. РЯБОВОЛ 1 , Л.О. РЯБОВОЛ1, П.Н. РЕНГАЧ 2 , \\ С.П. КОЦЮБА', М.А. МАКАРЧУК 1
}

\begin{abstract}
Основным препятствием для широкого внедрения тритикале в сельскохозяйственное производство являются низкие показатели качества зерна, в частности невысокое содержание в зерне белка и клейковины, а также низкие показатели качества клейковины. Гибридизация гексаплоидной тритикале с отдельными видами рода Triticum L. позволяет существенно расширить генофонд культуры и получить новые формы с улучшенными показателями качества. В системе скрещиваний целесообразно использовать пшеницу спельта, в зерне которой содержится до $25 \%$ белка. В Уманском национальном университете садоводства впервые в Украине проведено ряд исследований по гибридизации гексаплоидной тритикале с пшеницей спельта. Целью исследований было улучшение качества зерна тритикале при использовании межродовой гибридизации с пшеницей спельта и оценка созданных форм по основным показателям качества зерна. Результатом этих скрещиваний стало создание коллекции исходных форм тритикале, которая включает более 500 селекционных номеров. Полученное разнообразие форм тритикале по высоте растений разделили на три группы: среднестебельные, низкостебельные и короткостебельные. Отобранные лучшие образцы проанализировали по качеству зерна, в частности по содержанию белка и клейковины, качеству клейковины, массе 1000 семян и натуре зерна. Стандартом для среднестебельных образцов выступал сорт тритикале озимой Раритет, для низко- и короткостебельных образцов - сорт тритикале озимой Алкид. В результате проведенных исследований доказана возможность улучшения показателей качества зерна тритикале при использовании в селекционном процессе межродовой гибридизации с пшеницей спельта. Установлено, что по содержанию белка и клейковины в зерне среднестебельные генотипы №№ 455, 468 и 475, а также все низко- и короткостебельные образцы существенно превосходили сорт-стандарт. Наибольшим содержанием белка и клейковины в зерне выделялись образцы № 455 (13,9 \% белка, 30,2 \% клейковины), №468 (13,0 \% белка, 27,1 \% клейковины) и № 473 (12,8 \% белка, 28,0 \% клейковины). По совокупности показателей качества клейковины к I группе относились селекционные номера №№ $455,458,451$, 466, 488, 471 и 473, остальные образцы - ко II группе. По массе 1000 семян существенное превышение относительно стандарта наблюдалось у образцов № 455 (56,0 г), № 471 (55,3 г) и № 473 $(54,7$ г). По натурной массе зерна существенных различий между исследуемыми образцами в пределах каждой группы растений не обнаружили. Наиболее высокой натурой зерна выделились №№ 455 (700 г/л), 471 (690 г/л), 469 и 473 (685 г/л), 484 (682 г/л). В результате проведенных исследований отобраны два генотипа с высокими показателями качества зерна: среднестебельный образец № 455 (содержание белка 13,9 \%, клейковины I группы 30,2 \%, масса 1000 семян 56,0 г, натура зерна 700 г/л) и короткостебельный образец № 471 (содержание белка 13,6 \%, клейковины I группы 29,5\%, масса 1000 семян 55,3 г, натура зерна 690 г/л).
\end{abstract}

Ключевые слова: гексаплоидная тритикале, пшеница спельта, гибридизация, содержание белка, содержание клейковины, масса 1000 семян, натура зерна.

Гексаплоидная тритикале (Triticosecale Wittmack) выращивается в качестве кормовой, пищевой и технической культуры. Площади ее посевов достигают 4 млн га $(1,2)$. Приоритетные направления селекции тритикале - повышение урожайности, стабильность, улучшение показателей качества зерна (2-5). Низкие показатели качества зерна тритикале, в частности, невысокое содержание в зерне белка и клейковины, а также низкое качество клейковины, являются основным препятствием для широкого внедрения культуры в производство $(6,7)$. Поэтому усилия многих селекционеров направлены на улучшение качества зерна культуры (8-10). Недостаточно высокая пластичность сортов и селекционных форм тритикале, связана с ограниченным генетическим разнообразием исходного материала, нуждается в расширении генофонда и повышении различными методами эффективности ее селекции, в частности, гибридизации гексаплоидной тритикале с видами рода Triticum L. $(11,12)$. Как отмечают M.J. Hills c соавт. (13), это эффективный способ существенного расширения генетиче- 
ского разнообразия культуры. В скрещиваниях целесообразно использовать пшеницу спельта (Triticum spelta L.) - гексаплоидныq вид $(2 n=6 \times=42)$ с геномным составом, гомологичным пшенице мягкой (A山BD). B зерне пшеницы спельта содержится до $25 \%$ белка $(14,15)$. Показано $(16,17)$, что зерно спельты содержит незаменимые аминокислоты, которые не синтезируются в зерне пшеницы мягкой и не могут быть получены из продуктов животного происхождения.

Идея объединения генетического материала гексаплоидной тритикале со спельтой принадлежит Ф.Н. Парию $(11,18)$. В результате исследований по передаче генетического материала спельты при гибридизации гексаплоидной тритикале со спельтой создана генетическая коллекция Уманского национального университета садоводства, которая насчитывает более 500 образцов. В нее входят рекомбинантные формы, различающиеся по хозяйственно ценным и морфо-биологическими признаками.

В представленной работе мы впервые проанализировали формы гексаплоидной тритикале от скрещиваний со спельтой (по содержанию белка и клейковины, качеству клейковины, массе 1000 семян и натуре зерна) и доказали, что таким способом можно повысить качество зерна тритикале.

Целью исследований было улучшение характеристик зерна тритикале при использовании межродовой гибридизации со спельтой и оценка созданных форм по основным показателям качества.

Методика. Эксперименты по скрещиванию двух видов зерновых культур и стабилизации полученных потомков проводили в течение 20062012 годов (Центральная Лесостепь Украины, опытное поле Уманского национального университета садоводства, Черкасская обл.). При гибридизации в качестве материнского компонента использовали гексаплоидную тритикале (Triticosecale Wittmack) сортов Розовская 6, Розовская 7, Ладная, а в качестве опылителя - пшеницу спельту озимую (Triticum spelta L.) сорта Заря Украины. Гибридизацию проводили посредством кастрации цветков материнской формы с последующим принудительным опылением родительской формой. Глютениновые белков разделяли электрофоретически в PAAG по описанию (19).

Анализировали показатели качества зерна полученных селекционных образцов $\left(\mathrm{F}_{5-10}, 2012-2017\right.$ годы). Все фенологические наблюдения и анализы проводили в соответствии с «Государственной методикой квалификационной экспертизы сортов растений с определения показателей пригодности к распространению в Украине» (Український інститут експертизи сортів рослин, Київ, 2012, т. 2). Образцы тритикале группировали по высоте растений согласно классификации Г.В. Щипака (20). Продуктивность образцов оценивали в 5-кратной повторности на участках с учетной площадью $10 \mathrm{~m}^{2}$ при их размещении систематическим методом. Стандартом для среднестебельных образцов выступал сорт тритикале озимой Раритет, для низко- и короткостебельных - сорт тритикале озимой Алкид.

Экспериментальные данные анализировали статистически в программе Microsoft Excel 2010. При определении средних (M) вычисляли их стандартные ошибки $( \pm \mathrm{SEM})$. Наименьшую существенную разность $\left(\mathrm{HCP}_{05}\right)$ и коэффициент вариации $(C v)$ рассчитывали по методике Э.Р. Эрмантраута (21).

Результаты. Выделенные гибриды $\mathrm{F}_{1}$ характеризовались однотипностью по морфологическому строению колоса и общему габитусу растений. У растений доминировали признаки спельты (длинный рыхлый колос, грубая колосковая чешуя, безостость, ухудшенная обмолачиваемость).

При гибридизации гексаплоидной тритикале и пшеницы спельта 
получили в основном стерильное потомство $\mathrm{F}_{1}$. Только несколько образцов формировали фертильные пыльцевые зерна. На стерильность растений, полученных в результате отдаленной гибридизации, указывают многие авторы $(22,23)$. Так, гибриды первого поколения от скрещивания трехвидовой тритикале и мягкой пшеницы стерильны, как и в случае скрещивания тритикале и спельты. Причиной служит тот факт, что между геномами АВ тритикале и пшеницы проходит нормальная бивалентная конъюгация, поскольку эти геномы гомологичны. Хромосомы геномов тритикале $\mathrm{R}$ и пшеницы спельты D в мейозе не имеют пар для конъюгации. Процесс мейоза у них сопровождается значительными аномалиями, хромосомы формируют униваленты, которые не конъюгируют между собой. Это приводит к формированию анеуплоидных гамет, а впоследствии и анеуплоидных растений. Фертильность у таких растений резко снижается.

Исследования А.А. Першиной и Н.В. Трубачевой (23) показывают, что повысить фертильность пыльцы у стерильных гибридов $\mathrm{F}_{1}$ можно при помощи повторных скрещивай с одной из родительских форм. Мы в своих исследованиях также использовали этот прием и провели беккросные скрещивания гибридов $\mathrm{F}_{1}$ с гексаплоидной тритикале. У беккросированных потомков фенотипическое проявление признаков спельты было менее выражено. У гибридов $\mathrm{F}_{1} \mathrm{BC}_{1}$ изменчивость растений по фенотипу варьировала и выходила за пределы таковой у родительских форм.

Для стабилизации полученных образцов проводили самоопыление гибридов $\mathrm{F}_{1} \mathrm{BC}_{1}$ на протяжении нескольких поколений. После каждого следующего самоопыления процент стабильных и хорошо озерненных форм тритикале возрастал. После пятого самоопыления мы выделили 1137 растений с озерненностью колоса как у исходной формы, из них 316 были озерненными более чем на $80 \%, 471$ - на 71-80\% и 350 - на 61-70\%.

Электрофоретический анализ клейковинных белков зерна в PAAG выявил образцы с генетическим материалом от пшеницы спельта, которые несут специфические для спельты глиадин- и глютенин-кодирующие локусы в хромосомах первой гомеологической группы - Gli-Bl, Gli-Dl, GliB5, Gli-A3, Glu-A1, Glu-B1, Glu-D1.

Полученное разнообразие форм тритикале разделили на три группы по высоте растений согласно классификации Г.В. Щипака (20): среднестебельные (высота 100-120 см), низкостебельные (высота 80-100 см) и короткостебельные (высота 60-80 см). В каждой группе отобрали лучшие генотипы для дальнейшего анализа хозяйственно ценных показателей.

Основной целью гибридизации гексаплоидной тритикале с пшеницей спельта было генетическое улучшение тритикале, повышение содержание в зерне белка и клейковины, что позволило бы улучшить его хлебопекарные и технологические свойства. A.J. Lukaszewski (7) и J. Ukalska c соавт. (24) показали, что зерно тритикале содержит 10-12 \% белка, 20-25 \% клейковины и существенно уступает зерну пшеницы мягкой. К тем же выводам пришли другие исследователи $(8,10,17)$. В то же время признается, что потенциал улучшения культуры по продуктивности и качеству достаточно высок, а возможности ее применения разнообразны (25).

В нашем эксперименте в группе среднестебельных форм зафиксировано слабое варьирование по содержанию белка $(C v=8,9 \%)$ и среднее по содержанию клейковины $(C v=11,4 \%)$. Образец № 455 по содержанию белка существенно (на $2,2 \%$ при $\left.\mathrm{HCP}_{05}=0,4\right)$ превосходил стандарт (табл.). У этого же образца содержание клейковины (30,2 \%) было значительно выше (на 5,7 \% при $\left.\mathrm{HCP}_{05}=1,1\right)$ чем у стандарта. Другие анализируемые образцы превосходили стандарт на 0,5-9,8 \% (при $\left.\mathrm{HCP}_{05}=1,1\right)$. В той 
группе высокое содержание белка в зерне имели образцы № 468 (13,0 \%), № $475(12,5 \%)$ и № $458(12,3 \%)$. Они же превосходили сорт-стандарт по содержанию клейковины (на 0,7-1,8 \% при $\left.\mathrm{HCP}_{05}=1,1\right)$. Качество клейковины, соответствующее I группе, было выявлено у образцов № 455 и № 458. Другие среднестебельные формы по совокупности показателей качества клейковины относились ко II группе, что, в основном, связано с низким индексом деформации клейковины (ИДК) - главным показателем, характеризующим ее качество. По массе 1000 семян наблюдался наибольший размах вариации $(C v=18,7 \%)$. Существенно $\left(\mathrm{HCP}_{05}=2,1\right)$ превышал стандарт по этому показателю образец № 455 (56,0 г). Стоит отметить, что № 455 имеет наивысшие в опыте показатели содержания белка, клейковины, массы 1000 семян и натуры зерна (см. табл.).

Показатели качества зерна у селекционных образцов Triticosecale Wittmack/Tri-

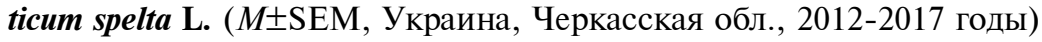

\begin{tabular}{|c|c|c|c|c|c|c|}
\hline \multirow{2}{*}{$\begin{array}{l}\text { Селекционный } \\
\text { образец }\end{array}$} & \multirow{2}{*}{ Белок, \% } & \multicolumn{3}{|c|}{ Клейковина } & \multirow{2}{*}{$\begin{array}{l}\text { Масса } 1000 \\
\text { семян, Г }\end{array}$} & \multirow{2}{*}{$\begin{array}{l}\text { Натура } \\
\text { зерна, г/л }\end{array}$} \\
\hline & & содержание, \% & ИДК & группа качества & & \\
\hline \multicolumn{7}{|c|}{ Среднестебе льны е $(100-120$ см $)$} \\
\hline Раритет (St) & $11,7 \pm 0,04$ & $25,5 \pm 0,11$ & 75 & I & $50,4 \pm 0,24$ & $670 \pm 12$ \\
\hline 455 & $13,9 \pm 0,02$ & $30,2 \pm 0,06$ & 75 & I & $56,0 \pm 0,32$ & $700 \pm 8$ \\
\hline 458 & $12,3 \pm 0,03$ & $26,2 \pm 0,07$ & 70 & I & $48,9 \pm 0,20$ & $660 \pm 14$ \\
\hline 461 & $11,5 \pm 0,04$ & $24,1 \pm 0,05$ & 60 & II & $48,4 \pm 0,21$ & $662 \pm 11$ \\
\hline 465 & $11,5 \pm 0,05$ & $24,6 \pm 0,07$ & 60 & II & $49,3 \pm 0,23$ & $665 \pm 9$ \\
\hline 468 & $13,0 \pm 0,03$ & $27,1 \pm 0,08$ & 55 & II & $50,2 \pm 0,25$ & $670 \pm 5$ \\
\hline 475 & $12,5 \pm 0,03$ & $27,3 \pm 0,09$ & 60 & II & $51,4 \pm 0,27$ & $678 \pm 8$ \\
\hline $\mathrm{HCP}_{05}$ & 0,4 & 1,1 & & & 2,1 & 28 \\
\hline Min & 11,5 & 24,1 & & & 48,4 & 665 \\
\hline Max & 13,9 & 30,2 & & & 56,0 & 700 \\
\hline$C v, \%$ & 8,9 & 11,4 & & & 18,7 & 10 \\
\hline $\mathrm{S}_{\mathrm{X}}, \%$ & 4,6 & 3,5 & & & 3,3 & 4,3 \\
\hline \multicolumn{7}{|c|}{ Низ косте бе льны е $(80-100$ см) } \\
\hline Алкид (St) & $10,0 \pm 0,04$ & $21,4 \pm 0,07$ & 45 & II & $50,2 \pm 0,25$ & $680 \pm 11$ \\
\hline 451 & $12,0 \pm 0,03$ & $26,0 \pm 0,07$ & 65 & I & $45,3 \pm 0,17$ & $650 \pm 14$ \\
\hline 467 & $12,2 \pm 0,04$ & $26,8 \pm 0,09$ & 50 & II & $49,6 \pm 0,21$ & $665 \pm 9$ \\
\hline 484 & $12,4 \pm 0,04$ & $26,9 \pm 0,04$ & 60 & II & $50,3 \pm 0,24$ & $682 \pm 11$ \\
\hline 486 & $11,7 \pm 0,03$ & $25,8 \pm 0,05$ & 70 & I & $47,7 \pm 0,18$ & $657 \pm 15$ \\
\hline 488 & $12,6 \pm 0,06$ & $27,7 \pm 0,12$ & 65 & I & $47,8 \pm 0,17$ & $660 \pm 12$ \\
\hline $\mathrm{HCP}_{05}$ & 0,4 & 1,1 & & & 2,0 & 28 \\
\hline Min & 10,0 & 21,4 & & & 45,3 & 650 \\
\hline Max & 12,6 & 27,7 & & & 50,3 & 682 \\
\hline$C v, \%$ & 8,5 & 11,8 & & & 10,2 & 10 \\
\hline $\mathrm{S}_{\mathrm{x}}, \%$ & 4,1 & 3,7 & & & 3,0 & 4,0 \\
\hline \multicolumn{7}{|c|}{ Короткостебельные $(60-80$ см $)$} \\
\hline Алкид $(\mathrm{St})$ & $10,0 \pm 0,04$ & $21,4 \pm 0,07$ & 45 & II & $50,2 \pm 0,25$ & $680 \pm 8$ \\
\hline 469 & $11,4 \pm 0,05$ & $25,8 \pm 0,10$ & 50 & II & $51,3 \pm 0,27$ & $685 \pm 6$ \\
\hline 470 & $12,6 \pm 0,03$ & $26,4 \pm 0,08$ & 70 & $\mathrm{I}$ & $49,7 \pm 0,22$ & $660 \pm 12$ \\
\hline 471 & $13,6 \pm 0,02$ & $29,5 \pm 0,05$ & 70 & I & $55,3 \pm 0,30$ & $690 \pm 7$ \\
\hline 473 & $12,8 \pm 0,03$ & $28,0 \pm 0,06$ & 65 & I & $54,7 \pm 0,29$ & $685 \pm 6$ \\
\hline 468 & $11,6 \pm 0,05$ & $26,1 \pm 0,09$ & 60 & II & $47,2 \pm 0,18$ & $655 \pm 11$ \\
\hline $\mathrm{HCP}_{05}$ & 0,5 & 1,2 & & & 1,9 & 27 \\
\hline Min & 10,0 & 21,4 & & & 47,2 & 655 \\
\hline Max & 13,6 & 29,5 & & & 54,7 & 690 \\
\hline$C v, \%$ & 10,0 & 15,7 & & & 17,2 & 10 \\
\hline $\mathrm{S}_{\mathrm{X}}, \%$ & 4,2 & 3,8 & & & 3,5 & 3,8 \\
\hline
\end{tabular}

Низко- и короткостебельные сорта тритикале в сельскохозяйственном производстве не используются. Как указывает R.D. Barnett c coaвт. (26), это обусловлено наличием отрицательной корреляция между высотой растений и продуктивностью. Однако, по мнению К.У. Куркиева (27), такие корреляции не имеют абсолютного характера и проявляются при неблагоприятных условиях окружающей среды. Поэтому формы тритикале, у которых высокие показатели качества и продуктивности сочетаются с низко- или короткотсбельностью, представляют особый интерес. 
В наших исследованиях все низко- и короткостебельные формы существенно превосходили стандарт по содержанию белка (на 1,4-3,6 \% при $\left.\mathrm{HCP}_{05}=0,4-0,5\right)$ и клейковины (на 4,4-8,1\% при $\left.\mathrm{HCP}_{05}=1,1-1,2\right)$ (см. табл.). Варьирование по содержанию клейковины было средним $(C v=11,8$ $15,7 \%)$, по содержанию белка в зерне - низким ( $C v=8,5-10,0 \%)$. Сорт Алкид выделялся высокой урожайностью, но имел низкие показатели качества: содержание белка в зерне не превышало $10,0 \%$, клейковины $21,4 \%$. В низкостебельной группе повышенное содержание белка (12,6 и $12,4 \%)$ и клейковины $(27,7$ и $26,9 \%)$ было зафиксировано соответственно у № 488 и № 484. Показатели качества клейковины в пределах I группы имели номера № 451, 486 и 488. Образец № 484 превосходил стандарт по массе 1000 семян на 0,1 г, тогда как образцы №№ 451, 467, 486 и 488 уступали ему по этому показателю. По натуре зерна выделились образцы № 484 (682 г/л), № 467 (665 г/л) и № 488 (660 г/л) (см. табл.).

Среди короткостебельных форм лучшим по содержанию белка и клейковины был образец № 471: в его зерне количество белка достигало $13,6 \%$, клейковины - 29,5 \%, что стало одним из самых высоких показателей в опыте. Незначительно уступали ему образцы № 470 (12,6\% белка, $26,4 \%$ клейковины) и № 473 (12,8 \% белка, 28,0 \% клейковины). Эти образцы отличались от остальных совокупностью высоких показателей массы 1000 семян и натуры зерна, а также качеством клейковины (I группа).

Таким образом, доказана возможность улучшения показателей качества зерна тритикале при использовании в селекционном процессе межродовой гибридизации с привлечением пшеницы спельты. Среди полученных гибридов отобраны две формы с высокими показателями качества зерна: среднестебельный образец № 455 (содержание белка в зерне 13,9 \%, клейковины I группы - 30,2 \%, масса 1000 семян 56,0 г, натура зерна 700 г/л) и короткостебельный образец № 471 (содержание белка 13,6 \%, клейковины I группы 29,5 \%, масса 1000 семян 55,3 г, натура зерна 690 г/л).

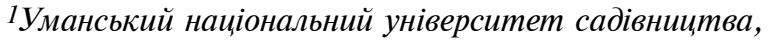

Кафедра генетики, селекції рослин та біотехнології, 20305 Україна, Черкаська обл., м. Умань, вул. Їнститутська, 1, e-mail: diordieva201443@gmail.com $₫$, Liudmila1511@ukr.net, Genetika2015@udau.edu.ua, bbkots@icloud.com, Marishka2708@ukr.net; 2 ФГБНУ Всероссийский НИИ сахарной свеклы и сахара им. А.Л. Мазлумова,

396030 Россия, Воронежская обл., Рамонский р-н, пос. ВНИИСС, 86, e-mail: RengacgPN@mail.ru
}

Поступила в редакцию 17 июля 2018 года

Sel’skokhozyaistvennaya biologiya [Agricultural Biology], 2019, V. 54, № 1, pp. 31-37

\title{
USE OF SPELT WHEAT (Triticum spelta L.) IN BREEDING TRITICALE (Triticosecale Wittmack) FOR GRAIN QUALITY
}

\author{
I.P. Diordiieval ${ }^{\text {, I.S. Riabovol }}$, L.O. Riabovol ${ }^{1}$, P.N. Rengach ${ }^{2}$, S.P. Kotsiuba ${ }^{1}$, \\ M.A. Makarchyk ${ }^{1}$
}

\footnotetext{
${ }^{1}$ Uman National University of Horticulture, Department of Genetics, Plant Breeding and Biotechnology, 1, Institutska vul., Uman, Cherkassy region, 20305 Ukraine, e-mail diordieva201443@gmail.com ( $₫$ corresponding author), Liudmila1511@ukr.net,Genetika2015@udau.edu.ua, bbkots@icloud.com, Marishka2708@ukr.net;

${ }_{2}^{2}$ Mazlumov All-Russian Research Institute of Sugar Beet and Sugar, 86, pos. VNIISS, Ramon Region, Voronezh Province, 396030 Russia, e-mail RengacgPN@mail.ru
} ORCID:

Diordiieva I.P. orcid.org/0000-0002-8534-583 Riabovol L.O. orcid.org/0000-0001-8988-4874

Riabovol I.S. orcid.org/0000-0003-4325-5313

The authors declare no conflict of interests

Received July 17, 2018

Rengach P.N. orcid.org/0000-0003-1807-3294

Kotsiuba S.P. orcid.org/0000-0001-8724-4240

Makarchyk M.A. orcid.org/0000-0003-4000-0921 doi: 10.15389 /agrobiology.2019.1.31eng 
Poor grain quality, mostly low proteins and gluten content, together with worse gluten quality, are the main obstacle to the widespread practical use of triticale. Hybridization of hexaploid triticale with certain Triticum species significantly expands the crop gene pool diversity and facilitates production of new forms with improved quality indicators. Spelt wheat is much suitable for crossing due to high protein content in grain (up to $25 \%$ ). The first Ukrainian study on hybridization between hexaploid triticale and spelt wheat was carried out in the Uman National University of Horticulture. The aim of the research was to improve triticale grain by intergeneric hybridization with spelt wheat and characterization of the hybrids for grain quality. The crosses resulted in a collection of more than 500 breeding samples of triticale which were grouped by plant height as medium, dwarf and short-stem forms. The best samples were analyzed for grain quality, i.e. content of proteins and gluten, the gluten quality, the 1000-seed weight and grain unite. Winter triticale Rarytet cultivar was the standard for medium height samples, and Alkid cultivar for low and short stem samples. Our research shows the improvement of triticale grain quality by intergeneric hybridization with spelt. Genotypes No. 455, 468 and 475 of medium height group, together with all dwarf and short-stem samples significantly exceeded the standards in grain protein and gluten content. The samples Nos. 455 (13.9\% protein, 30.2\% gluten), 468 (13.0\% protein, $27.1 \%$ gluten) and 473 (12.8\% protein, $28.0 \%$ gluten) outstood for grain protein and gluten concentration. By the set of gluten quality indicators, the samples Nos. 455, 458, 451, 466, 488, 471 and 473 were assigned to group I, the rest of the samples belonged to group II. The samples Nos. 455 (56.0 g), $471(55.3 \mathrm{~g})$ and 473 (54.7 g) significantly surpass the standard in 1000-seed weight. No significant differences were found between the samples within each group for grain unit values. The highest values have Nos. 455 (700 g/l), 471 (690 g/l), 469 and $473(685 \mathrm{~g} / \mathrm{l}), 484(682 \mathrm{~g} / \mathrm{l})$. As a result, two genotypes with high indicators of grain quality were selected, i.e. medium height sample No. 455 with protein content $13.9 \%$, group I gluten $30.2 \%, 1000$ seed weight $56.0 \mathrm{~g}$, grain unit $700 \mathrm{~g} / \mathrm{l}$, and short-stem sample No. 471 with protein content $13.6 \%$, group I gluten $29.5 \%$, 1000-seed weight $55.3 \mathrm{~g}$, and grain unit value $690 \mathrm{~g} / \mathrm{l}$ ).

Keywords: Triticosecale Wittmack, hexaploid triticale, Triticum spelta L., spelt wheat, hybridization, protein content, gluten content, 1000-seed weight, grain unite.

\section{REFEREN CES}

1. Estrada-Campuzano G., Slafer G.A., Miralles D.J. Differences in yield, biomass and their components between triticale and wheat grown under contrasting water and nitrogen environments. Field Crops Research, 2012, 128: 167-179 (doi: 10.1016/j.fcr.2012.01.003).

2. Grebennikova I.G., Aleinikov A.F., Stepochkin P.I. Vychislitel'nye tekhnologii, 2016, 1: 53-64 (in Russ.).

3. Rybalka O.I., Morgun V.V., Morgun B.V., Pochinok V.M. Fiziologiya rastenii i genetika, 2015, 2: 95-111 (in Ukr.).

4. Shchipak G.V. Selektsiya polevykh kul'tur, 2008, 5: 42-88 (in Ukr.).

5. Dennett A.L., Cooper K.V., Trethowan R.M. The genotypic and phenotypic interaction of wheat and rye storage proteins in primary triticale. Euphytica, 2013, 194: 235-242 (doi: 10.1007/s10681-013-0950-y).

6. Leshchenko N.I., Shakirzyanov A.Kh., Myzgaeva V.A., Karachurina G.R. Dostizheniya nauki $i$ tekhniki APK, 2010, 1: 16-19 (in Russ.).

7. Lukaszewski A.J. Cytogenetically engineered rye chromosomes $1 \mathrm{R}$ to improve bread-making quality of hexaploid triticale. Crop Sci., 2007, 46(5): 2183-2194 (doi: 10.2135/cropsci2006.03.0135).

8. Grebtsova L.N. Novosti nauki Kazakhstana, 2013, 3: 155-159 (in Russ.).

9. Ittu Gh., Saulescu N., Ittu M., Mustatea P. Achievements in triticale breeding $(\times$ Triticosecale Witt.). I.N.C.D.A. Annals Fundulea, 2007, 75: 73-82.

10. Wos H., Brzezinski W.J., Arseniuk E., Zimny J., Wos J. Triticale of improved bread-making quality Proc. 18th EUCARPIA General Congress «Modern variety breeding for present and future needs», 9-12 Sep 2008, Valencia-Spain. Valencia, 2008: 661.

11. Diordieva I.P., Parii F.N. Geneticheskie resursy rastenii, 2014, 5: 42-53 (in Ukr.).

12. Grabovets A.I., Fomenko M.A. Zernobobovye i krupyanye kul'tury, 2013, 2(6): 41-47 (in Russ.).

13. Hills M.J., Hall L.M., Messenger D.F., Graf R.J., Beres B.L., Eudes F. Evaluation of crossability between triticale ( $\times$ Triticosecale Wittmack) and common wheat, durum wheat and rye. Environ. Biosafety Res., 2007, 6: 249-257 (doi: 10.1051/ebr:2007046).

14. Dvorak J., Deal K.R., Luo M.C., You F.M., Borstel K.V., Dehghani H. The origin of spelt and free-threshing hexaploid wheat. The Journal of Heredity, 2012, 103(3): 426-441 (doi: 10.1093/jhered/esr152).

15. Zielinski H., Ceglinska A., Michalska A. Bioactive compounds in spelt bread. Eur. Food Res. Technolol., 2008, 226: 537-544 (doi: 10.1007/s00217-007-0568-1). 
16. Blatter R.H.E, Jacomet S., Schlumbaum A. Spelt-specific alleles in HMW glutenin genes from modern and historical European spelt (Triticum spelta L.). Theor. Appl. Genet., 2002, 104(2-3): 329-337 (doi: 10.1007/s001220100680).

17. Guzmán C., Xiao Y., Crossa J., González-Santoyo H., Huerta J., Singh R., Dreisigacker S. Sources of the highly expressed wheat bread making (wbm) gene in CIMMYT spring wheat germplasm and its effect on processing and bread-making quality. Euphytica, 2016, 209: 689-692 (doi: 10.1007/s10681-016-1659-5).

18. Parii F.N., Diordieva I.P. Sozdanie chetyrekhvidovykh form tritikale. Zemledelie $i$ zashchita rastenii, 2015, 5(102): 35-42.

19. Ng P.K.W., Sconlon M.G., Bushuk W.A. Catalog of biochemical fingerprints of registered Canadian wheat cultivars by electrophoresis and high-perpformanse liquid chromatography. University of Manitoba, Winnipeg, 1988

20. Shchipak G.V. V sbornike: Spetsial'naya selektsiya i semenovodstvo polevykh kul'tur [In: Special selection and seed production of field crops]. Khar'kov, 2010: 70-107 (in Russ.).

21. Ermantraut E.R., Gudz' V.P. Materialy Mezhdarodnoi nauchno-prakticheskoi konferentsii «Sovremennye problemy opytnogo dela» [Proc. Int. Conf. «Current problems of experiment design»]. St. Petersburg, 2000: 13-134 (in Russ.).

22. Maksimov N.G. Selektsiya i semenovodstvo, 2011, 99: 30-38 (in Russ.).

23. Pershina A.A., Trubacheva N.V. Vavilovskii zhurnal genetiki i selektsii, 2016, 20(4): 416-425 (doi: 10.18699/VJ16.082) (in Russ.).

24. Ukalska J., Kociuba W. Phenotypical diversity of winter triticale genotypes collected in the Polish gene bank between 1982 and 2008 with regard to major quantitative traits. Field Crops Research, 2013, 149: 203-212 (doi: 10.1016/j.fcr.2013.05.010).

25. Ayalew H., Kumssa T.T., Butler T.J., Ma X.-F. Triticale improvement for forage and cover crop uses in the southern great plains of the United States. Front. Plant Sci., 2018, 9: 1130 (doi: 10.3389/fpls.2018.01130).

26. Barnett R.D., Blount A.R., Pfahler P. L., Bruckner P.L., Wesenberg D.M., Johnson J.W. Environmental stability and heritability estimates for grain yield and test weight in triticale. J. Appl. Genet., 2006, 47: 207-213 (doi: 10.1007/BF03194625).

27. Kurkiev K.U. Genetika, 2007, 9: 1269-1272 (in Russ.). 